\title{
Suifaction: typological reflections on the evolution of the self
}

\begin{abstract}
The human person, whose definition serves as the touchstone according to which good must be distinguished from evil, is considered as sacred, in what one might call the ritual sense of the word (sc. in the thinking of Kant and Rousseau - AKP). It has something of that transcendental majesty which the churches of all times have given to their Gods. It is conceived as being invested with that mysterious property which creates an empty space around holy objects, which keeps them away from profane contacts and which draws them away from ordinary life. And it is exactly this feature which induces the respect of which it is the object. Whoever makes an attempt on a man's life, on a man's liberty, on a man's honour inspires us with a feeling of horror, in every way analogous to that which the believer experiences when he sees his idol profaned. Such a morality is therefore not simply a hygienic discipline or a wise principle of economy. It is a religion of which man is, at the same time, both believer and God. But this religion is individualistic, since it has man as its object, and since man is, by definition, an individual. Indeed there is no system whose individualism is more uncompromising. Nowhere are the rights of man affirmed more energetically, since the individual is here placed on the level of sacrosanct objects; nowhere is he more jealously protected from external encroachments, whatever their source.
\end{abstract}

(Lukes 1969, 21f; Durkheim 1898, 6) ${ }^{1}$

How can one approach a notoriously tantalising and yet intellectually challenging topic revolving around historical processes of religious individualisation? The question is not only inextricably related to the issue of modernity but it has also in conjunction with this topic been the subject of intense discussion among contemporary thinkers like Foucault, Habermas, Sorabji and Taylor. I shall not enter this philosophical conversation although my examination does have more than a tangential relationship to it. My main concern lies in establishing a typology that will allow us to make some finer gradations in our talk about processes of individualisation in the history of culture, religion included. ${ }^{2}$ In this way, I cast my nets wider

1 For the historical background of the reflections in relation to the Dreyfuss Affair, see Lukes 1969, 14-9, and 1972, 338-44. Following the editors' wish, all non-English texts are provided in translation. References to the texts in their original language are given as additional page numbers.

2 I do not think it makes sense to speak about religion as a separate sphere independent from culture until modernity. Surely one can speak about religion - from a third order perspective - in relation to pre-modern cultures but it is on the premise that the conflation between culture and religion is acknowledged (cf. Petersen 2017c; 2017d). Although it has taken considerable time to make this insight general in scholarship, it is a basic tenet of Weber and Durkheim, see Weber 1963, 546-54, and Durkheim 2007, 47.542.

2 Open Access. (C) 2019 Anders Klostergaard Petersen, published by De Gruyter. (c) BY-NC-ND This work is licensed under a Creative Commons Attribution-NonCommercial-NoDerivatives 4.0 International License. https://doi.org/10.1515/9783110580853-008 
than the Erfurt project by examining historical processes of individualisation in general rather than confining the study to processes of religious individualisation only. I do this for two reasons. First, such an expansion is needed to answer the question of historical processes of religious individualisation specifically. Second, since throughout most of human evolution religion and culture have been overlapping entities there is the more reason to expand the analytical horizon. To some my taxonomical ruminations may sound like a dull and old-fashioned enterprise founded on the idea of reifying particular epochs and geographical areas as constituting important steppingstones on a long journey eventually culminating in Western modernity. Although I think of certain historical processes as archetypal and decisive for the subsequent developments, I do not assert typologies to mirror reality in any 1:1 relationship. Typologies are models that can be good to think with inasmuch as they provide us with a grid creating a plausible framework for understanding the world (here understood in Popper's wider trichotomous sense of worlds). If we refrain from operating with some basic taxonomical distinctions in relation to selfhood, we shall continuously be haunted by elusive categories and misunderstandings such as those found in the discussions pertaining to the emergence of the individual. The more so, since there is an obvious risk, as can also be seen from the scholarly literature on the subject, that all forms of selfhood come to be measured in relation to modern Western forms of individualisation which render them deficient in one way or the other.

Admittedly, my study has an ambitious longitudinal character, but to be able to speak about historical processes of individualisation we need to know what we are talking about. How is it possible to think about individualisation if there is no individual in the first place, or if we have not clarified the meaning of the adopted terms? ${ }^{3}$ And even more so, how can there be individualisation if there is no self? Some may arguably object that obviously there is a self (Searle 2001, 75). If that is the case, however, we should be able also to point to the emergence of this self, just as we should be able to delimit ourselves from periods and species for which we are not prepared to talk about it, let alone the individual. ${ }^{4}$ In other words,

3 Despite several excellent essays, Arweiler and Möller 2008 is symptomatic of the problems arising from a lack of typological and definitional considerations, when taking up the subject of self-understanding. Apart from Gill's essay (2008, 359-61), there is hardly anywhere in the book where the central concepts relating to self-understanding and individualisation are defined in relation to each other.

4 I want to develop the Durkheimian-Maussian argument of selfhood by taking into account not only what we today know about animals other than humans but also about possible differences with respect to self-awareness in the hominin lineage. In the Maussian understanding, self-awareness served as a default assumption for the examination $(1938,265)$. 
typological reflections on the evolution of the self and different manifestations of selfhood are inevitable if we want to pursue the question of historical processes of individualisation, let alone religious individualisation. ${ }^{5}$

Second, I risk my neck by arguing that a decisive change in self-awareness and, thereby, self-understanding took place in some elite segments at the transition from urban forms to kosmos types of religion: that which Bellah designated the change from archaic to Axial age forms of religion. ${ }^{6}$ I assert that this ideological transformation driven by changed socio-material conditions in some distinct Eurasian cultures had a lasting effect on subsequent forms of individualisation, and that parallel changes can be documented in cultures outside this geographical area and time period, when comparable socio-material developments were at hand. Here I shall focus on one particularly prominent feature of kosmos religion, the element of suifaction as self-cultivation. I shall conclude by discussing two examples testifying to the change in suifaction, with respect to self-cultivation or training, that the kosmos religions gave rise to.

\section{Some crucial problems}

As implied by the term individual there never was and never will be a self who exemplifies an entire epoch or geographical area. Someone is always different from anyone, just as the particular one is different from everyone (Burridge 1979); but these differences aside there are patterns of meaning that the different selves belonging to different socio-cultural segments of society embody at different historical epochs and geographical areas. It is to these patterns that I turn my attention by focusing on processes of selfhood rather than understanding it as denoting a state or an acquisition (cf. Gordon 2015, 367). Suifaction is always a matter of flux rather than a possession one may obtain once and for all.

5 I agree with Mauss who asserted on the issue of individualisation that it is a subject belonging to social history. Thus Mauss in teasing apart the notion strove to examine it on the basis of laws, religions, habits, and social and intellectual structures $(1938,265)$. I agree with him that we should continue the work on notions of suifaction to obtain a better and more thorough understanding of the subject $(1938,281)$.

6 I now prefer to designate Axial age religions as kosmos forms of religion in order to detach the argument from its terminologically heavy reliance upon a Eurasian perspective and an idealist accentuation at the cost of socio-material preconditions for the distinctly cultural evolution. Due to constraints of space I shall have to exclude the important judicial and economic dimension of selfhood from the reflections. Obviously that will have to be taken into consideration in the future to achieve a more thorough and complete understanding. 
Initially, however, I shall express a word of caution. As Martin has noted, there is an imminent risk that when searching for ideologically loaded phenomena such as questions relating to the emergence of the individual and individualism, one is likely to find them in those geographical areas and periods for which one has a preference (1994, 118f.). I do not argue that all we find is a matter of self-reflection only, but any attempt to search for historical processes of individualisation inevitably involves the question of the origin of an ideologically particularly moot phenomenon and hence should take the risk of presentism seriously (cf. de Certeau 1975, 40, 58).

In other words, searching for processes of individualisation, and the related issues of the emergence of the individual and individualism as a concomitant ideology requires methodological and theoretical rigour in order to avoid blunt self-reflection. Yet, it is analytically not only viable but also advantageous to operate with a continuum on which one may insert different caesurae enabling us to differentiate between diverse manifestations of selfhood, processes of individualisation and related ideologies pertaining to the understanding of the self with respect to the wider society, one's community and family. Other scholars have also emphasised the presentist ring related to the search for the emergence of the individual and, therefore also by necessity, processes of individualisation (cf. Pelling 1990, v). Personally, I do not think that presentism constitutes a problem per se, since it pertains to any historical study. As long as one succeeds in handling the problem in a cognisant and methodologically rigorous way, there is no reason to stumble at the presentist dimension. The more so, since it would be scholarly detrimental were we to dispose of raising some of the grander problems pertaining to cultural history. In fact, it is an important exercise insofar as it diminishes the risk of falling victim to prejudicial thinking by forcing us to tackle a patently thorny question. The enterprise becomes problematic only if the presentism is not counterweighted by a parallel acknowledgement of alterity. I do not have any hobby horses in calling things by different names as long as we can retain lucidity in the nomenclature adopted, and agree on what exactly we are in pursuit of in the worlds examined (cf. Petersen 2017c; 2017d). In saying this I do not expect that other members of the project will necessarily agree, let alone embrace, my taxonomical terminology, ${ }^{7}$ nor do I assert that it correlates with historical realities in any direct way. I present it as a model only, the virtue of which should be judged on its ability to instigate a more thorough and thick thinking

7 I agree with Gordon (2015), but contrary to him I think we need a typology to know what we are talking about. 
on the issue. ${ }^{8}$ In other words, the merit of the typology lies in its ability to offer a model that is good to think with and prevents us from making blunt generalisations thwarting out the nuances between different epochs, geographical areas, and diverse socio-cultural segments, while simultaneously acknowledging the existence of certain patterns in cultural history. I do not think it is possible to come to any agreement on a fixed point in history which may be said to constitute the dawn of the individual and the emergence of individualism. There may be different ways to approach the subject and to conceptualise it, as different contributions written over the years as part of the Erfurt project vividly demonstrate. The merits of the diverse attempts should be assessed on their capacity to create a plausible overarching view projected onto history and relating to suifaction.

The key focus of the project is extremely valuable in this regard. By downgrading the quest for the origin of (religious) individualism and the emergence of the individual in favour of casting light on historical processes of religious individualisation, the endeavour allows for greater versatility and pluriformity. It opens up for a more comprehensive view that enables us to operate with different processes of suifaction and, therefore, to apply the perspective to a variety of historical eras and geographical areas. When, for instance, Burckhardt dated individualism to the Italian Renaissance, this dating made excellent sense in light of his overall argument $(1985,93) .{ }^{9}$ At the same time, however, it makes sense from another perspective to argue that Burckhardt was wrong if by individualism one understands the situation epitomised by Kant and Rousseau and elegantly described by Durkheim in my preamble text (cf. Makari 2015, 267-97, 397-424). Admittedly, Kant does not directly touch upon individualism in his famous definition of enlightenment. In the subsequent tradition, however, his understanding became closely connected with the birth of the individual and individualism, since the latter came to designate the being of the autonomous enlightened citizen. Based on this view, it hardly makes sense to speak about the individual and individualism prior to Enlightenment. ${ }^{10}$ In the Beantwortung der Frage: Was Ist Aufklärung, Kant asserts that enlightenment consists in:

[...] human's exodus from his self-imposed nonage (aus seiner selbst verschuldeten Unmündigkeit). Nonage is the incapacity to use one's own understanding without another person's guidance. The nonage is self-imposed when its cause springs not from a lack of

8 For the distinct function of models in relation to method and theory, see Jensen 2009.

9 Seidentrop 2014, 334-48, argues against Burckhardt by dating individualism and, hence, modernity to early liberalism of the 16th and 17th century, while also emphasising this tradition's background in Christianity (cf. 51-110, 349-63).

10 The Enlightenment understanding also constitutes the point of departure for Dumont's reflections 1983, 20. 
understanding but in indecisiveness and absence of courage to be guided by one's own understanding not led by another. "Sapere aude!" "Have courage to use your own understanding!” therefore, is the adage of Enlightenment.

(Berlinische Monatschrift 30. September 1784 - my translation)

If, conversely, one understands individualism as being intrinsically related to political autonomy it is difficult even to use the notion with respect to Enlightenment, since neither Kant's Prussia nor Rousseau's France, or for that matter any other European state of the age, subscribed to a form of political independence of the individual citizens that we would acknowledge as identical with political autonomy. At the same time, one has to add that if one were to define individualism along the lines of Kant's understanding of the enlightened self, even today only few people would qualify as, in fact, being individuals - which points to another general problem in reflections on the issue. Each time we insert a caesura on the continuum eventually leading to stronger forms of individualism, we have to acknowledge that the changes did obviously not happen from one day to the next, nor were they extended to all members of society. It took a long time before what originally emerged as an elite phenomenon disseminated to wider segments of the population. And even when we grant the special role of social and cultural entrepreneurs in paving the way for new forms of selfhood, ${ }^{11}$ these entrepreneurs presumably also balkanised or oscillated between different representations of personhood embedded in different ideologies and ontologies. ${ }^{12}$

In my view, much of the critique voiced against an allegedly Western hegemonic self-eulogy of Western modernity as the breeding ground for the emergence of the individual with a concomitant ideology falters on the ground, when the modifications and nuances inherent in this view are taken into consideration. Based on such an understanding I also think it is presumptuous to deny that in the various Enlightenment movements there was a particularly strong emphasis placed on the concept of the individual. In fact, it makes sense to argue, along with Durkheim, Dumont, Taylor and a whole series of other notable thinkers, that in terms of intellectual and philosophical history, Enlightenment and, I would add, Romanticism in effect constituted the period during which the emergence of the individual understood as an autonomous being independent of all authorities other than one's own reasoning and choices came into being supported by a concomitant ideology. This view does not imply that there could be no sense of

11 For the role of social and cultural entrepreneurs in paving the way for transitions in intellectual history in particular in relation to the Axial age, see Abrutyn 2014.

12 For the idea of balkanisation as crucial for examinations of ancient cultures, see Veyne 1983, although he uses the term exclusively in relation to religious representations. 
selfhood in preceding eras or that other non-Western cultures were void of representations of selfhood. What the argument amounts to is the fact that Enlightenment in conjunction with Romanticism, in terms of intellectual history and philosophy, set a new frame of reference for how the self could be envisaged and understood in relation to an unconditional instance. But surely nothing in evolution emerges ex nihilo. Any novelty is built on existing vestiges, since natural selection needs something to work with and ratchet onto. The same pertains to other selection mechanisms that we need to acknowledge if we want to give a plausible description of evolution relating to intentional agents such as Homo sapiens. ${ }^{13}$ This connects to both specifically biological and cultural evolution, as Bellah, with respect to the latter, emphasises in an epitome of his thinking: 'Nothing is ever lost,' that is, nothing decisive (2005, 72, 83; 2011).

So let us return to the evolutionary issue and clarify how the question may be posed: What does it take for selfhood to come into existence? There is ongoing and vibrant research in the behavioural sciences and primatology that argues for extending the notion of selfhood also to include animals other than humans. On the background of such insights the taxonomical considerations pertaining to selfhood do not become less crucial. What exactly do we mean when using the concept of self, and how do we make the epistemological transition from self to individualisation? I agree with Dumont that although the emergence of the individual surely represents a late Western phenomenon such a view does not take away the burden of examining the historical presuppositions which eventually led to the modern phenomena (see also Mauss 1938):

Thus when we speak of man as an individual, we designate two concepts at once: an object out there, and a value. Comparison obliges us to distinguish analytically these two aspects: one, the empirical subject of speech, thought, and will, the individual sample of mankind, as found in all societies; and, two, the independent, autonomous, and thus essentially nonsocial moral being, who carries out paramount values and is found primarily in our modern ideology of man and society. From that point of view, there emerge two kinds of societies. Where the individual is a paramount value, I speak of individualism. In the opposite case, where the paramount value lies in society as a whole, I speak of holism

$(1986,24 ; 1983,34 f .)^{14}$

Unlike Dumont and Taylor I am not particularly focused on what led to the modern Western notion of individuality and its undergirding ideology of individualism. I am more interested in different notions of selfhood and in how they evolved

13 For an elaboration of the various selection mechanisms at play in the hominin lineage, see Turner et al. 2018.

14 Cf. also idem, 1983, 21 and Taylor 1989, 111-42. 
under particular circumstances. I do not think there was any unidirectional or irreversible movement from say antiquity to modernity stretching from Paul over Augustine and Luther to Kant and Kierkegaard. There were periods of increased individualisation in certain social segments, just as there have been eras of deindividualisation as well as continuous reciprocal processes of individualisation and de-individualisation. That said, however, I also assert that in hindsight one can point to important configurations in the thinking about and the instantiation of the self that eventually manifested themselves in modern Western ideologies about individualism, as exemplified in the lonely figure of Friedrich's famous 'Wanderer above the Mist' painting or the anguished self of Kierkegaard's philosophical-theological oeuvre painstakingly making its own existential choice by being suspended above 70,000 fathoms of water (cf. Petersen 2004).

In line with these considerations, my concluding examples are meant to demonstrate how one particularly strong notion of selfhood emerged at a crucial time in history on the Eurasian continent at the transition from complex urban forms of religion to early kosmos types of religion. ${ }^{15}$ Yet, it would be wrong to date the emergence of the individual to this epoch, just as it would be fallacious to use this terminology with respect to the pre-modern period, ${ }^{16}$ but certainly one can, in some segments of these past Eurasian societies, see a much stronger concept of the self that begins to take form in difference to urban forms of religion (Petersen 2013a): a transition that paved the way for a distinctly new type of religion that eventually became disseminated to much wider segments of the population. In this way, the examples demonstrate what may be gained by operating with a typology that, on the one hand, allows for terminological differences between different notions of selfhood diverging from each other by the degree of suifaction

15 In Bellah's terminology this transition is dubbed the movement from archaic to Axial age types of religion. I adhere to his general framework of evolutionary thinking about religion, but as noted in fn. 6, I have abandoned his terminology for two reasons. First, for comparative purposes it is important to make it less dependent upon the Eurasian development and to make the nomenclature more stringent in terms of consistent terminology. Second, it is crucial to lay emphasis on the socio-material presuppositions for any cultural development to take place. Hence, I divide the history of religion into the following stages: 1) gatherer-hunters' religion; semi-nomadic religion 2) early agricultural religion; complex agricultural religion; 3) early urban religion; complex urban religion; 4) early kosmos religion; complex kosmos religion; 5) early global religion; complex global religion. Often the forms of religion are overlapping, just as some of them have persisted unto the present although influenced by subsequent forms of religions. 16 See, for instance, Bonnet 2013, Graf 2013, and Woolf 2013. Whereas Bonnet rejects the term individualisation (49), Graf emphasises its limitations (132f.) for an appraisal of ancient religion, and Woolf underlines 'how there were, properly speaking, neither individuals nor religions in Roman Antiquity' (155). 
involved, and, on the other hand, enables us to see other periods and geographical areas during which individualisation processes also came to the fore of attention.

\section{A Durkheimian take on selfhood}

As a point of departure, I find it hard to imagine a world inhabited by humans not capable of making a simple distinction between individual members and the group, but the same pertains to other apes. Evidently they are also capable of making differentiations between themselves, kin and other members of the group. And by the same reasoning, we should grant the same to our hominin predecessors. Self-recognition is found with many animals, but if that is so what exactly does it mean to speak about and conceptualise a self, and what are the differences between hominin self-recognition and that of other animals?

The difference between member and group is a key to understanding human culture and society in general. The self only attains reality by recognising how at one and the same time it constitutes a self by being different from the group and how its existence is contingent upon its group membership: a double movement that takes place between individual awareness and collective consciousness (Durkheim 2007, 344). Human beings are homines duplices suspended between culture and biology, group and self. We may push this Durkheimian understanding further by taking recent evolutionary insights into consideration.

When our hominin predecessors left the arboreal areas for the open grassland sometime around 2, 5 million years ago, they had to undergo drastic changes to survive in their new habitat. As we can see from our ape cousins in the pan lineage, from which we split apart some 6.5 million years ago and with which we share almost 99 percent of our genes, they are, as other apes, basically nepotistic, despotic and self-centred. Their form of social life consists in fission-fusion groups and involves at the most a number of peers around 100. The same pertains to the other apes such as orangutans and gorillas, from the lineages of which we are further apart. In calling apes despotic and egoistic I do not mean to castigate them. Had our predecessors stayed in the woodlands, we would have been the same. It is the niche that we came to inhabit which, in interchange with our genome, changed our nature. To survive on the savannah it was crucial to engage in different forms of co-operation at a far more stable scale compared to the momentary types of collaboration that we find among other apes. It was decisive to engage in alliances to protect oneself not only against predators but also to be able to sustain one's life by getting access to prey (Bickerton 2009, 123f.). During these millions of years, natural selection worked in such a way as to result 
in a number of remarkable changes in hominin anatomy crucial for its survival in a new biotope. Bipedalism was decisive in order to be able to view over the grass and detect predators in due time. Important changes on the upper arm and shoulder paved the way for hominins' possibility of defending themselves against predators by standing at a safe distance and throwing stones at attacking animals, since the human shoulder came to work as a catapult (Turchin 2016, 95-110). Bipedalism also led to enlargement of the larynx and elongation of the vocal cords that in turn led to greater versatility in sounds produced and, thereby, provided physical presuppositions for the later development of language.

In several books, Turner argues that with the move to the savannah the hominin palette of emotions was also considerably developed with respect to the four primary emotions of fear, anger, sadness and happiness, found also among the other apes (see, for example, Turner and Maryanski 2008, Turner et al. 2018). The development of secondary emotions like shame and guilt was important for an ape that, given the drastic change in environment, had to survive by means of stable alliances for which it was not genetically disposed (Turner et al. 2018; Henrich 2016; Turchin 2016). In fact, guilt and shame are necessary prerequisites for an animal to set up a strong sense of morality whereby the self is able to reflect on its ability or failure to comply with the norms of the group. In Turner's view the emergence of religion should also be seen in this context. Ultimately it should be thought of as an evolutionary by-product resulting from the expansion of the hominin palette of emotions. ${ }^{17}$ Obviously religion constitutes an impure concept inasmuch as it is comprised of elements originating in different evolutionary contexts. We certainly find ritualised behaviour in a number of animals, but what we do not find among animals other than later hominins is symbolisation relating to religion.

Although religion originally constituted an evolutionary by-product relating to the previously mentioned expansion of the hominin palette of emotions, it came to have adaptive functions for group-bonding. Emotions are evanescent. The positive values pertaining to emotions for social cohesion are, given their ephemeral nature, difficult to maintain over time. At this point religion became crucial in providing the means for stabilising the group by bestowing upon it a more constant foundation for upholding positive emotions. By directing their emotions towards an emblem - symbolically and indexically signifying the fundamental values of the community - members of the group could maintain the positive emotions over time and hence strengthen the bonds uniting them into a coalition.

17 When talking about religion I use the term from a third order perspective. I can easily subscribe to Jensen's definition of religion as 'cognitive and semantic networks comprising ideas, behaviours and institutions in relation to counter-intuitive superhuman agents, objects and posits' $(2014,8)$. 
In continuity of Durkheim, I think of religion as a storage battery in which the group - consisting of individual selves - invest positive emotions in the emblem on behalf of the collective and at the cost of the individuals (2007, 91, 337f., 342). But subsequent to the group gathering around the emblem and celebrating its fundamental values, the adherence and ongoing commitment to these ideals, indexically symbolised by the emblem, will inevitably fade away. Therefore, a new gathering or re-presentation of the cult is needed to reaffirm the significance of the emblem and the concomitant values:

\begin{abstract}
Without symbols, moreover, social feelings could have only an unstable existence. Those feelings are very strong so long as men are assembled, mutually influencing one another, but when the gathering is over, they survive only in the form of memories that gradually dim and fade away if left to themselves. Since the group is no longer present and active, the individual temperaments quickly take over again. Wild passions that could unleash themselves in the midst of a crowd cool and die down once the crowd has dispersed, and individuals wonder with amazement how they could let themselves be carried so far out of character. But if the movements by which these feelings have been expressed eventually become inscribed on things that are durable, then they too become durable. These things keep bringing the feelings to individual minds and keep them perpetually aroused, just as would happen if the cause first called them forth was still acting. Thus, while emblematizing (l'emblématisme) is necessary if society is to become conscious of itself, so is it no less indispensable in perpetuating that consciousness.
\end{abstract}

(Durkheim 1995, 232; 2007, 344f.)

The fundamental understanding of human beings as homines duplices whose existence is suspended between biology and culture puts religion into focus if humans are to establish and preserve culture and community (Durkheim 2007, 119f., cf. 353). Durkheim's perspicacious acknowledgement of the frailty of community and culture is an important counterweight to a long tradition of thinking in the humanities and social sciences about culture as an instrument of suppression. Far from understanding culture as a means to exert power, although certainly acknowledging this dimension as well, Durkheim emphasised the vulnerability of culture and society and pointed to religion as the means to establish and uphold community. By virtue of being as a storage battery into which the group invests its positive emotions, religion can, within a split second, also evolve into a nasty phenomenon if the community - dependent on its socio-material situation - instead invests negative emotions into the battery. Thus, the positive effects of religion may by the same token be turned 180 degrees around and develop into something repugnant, as history patently demonstrates. I underline this point in order not to be understood to argue for the positive effects of religion only. Similarly, I do not as indicated argue that religion appeared $a b$ ovo. 
Religion could ratchet onto ritualised behaviour found among numerous animals (for the ratchet effect, see Tomasello 1999; 2009; 2016). With the emergence of religion, however, the way was paved for the introduction of a reward and punishment system implemented within the group and imposed on its individual members to diminish the risks of free-riding, cheating and betrayal in the group (Haidt 2012, 285-318). Inasmuch as humans - similar to their ape cousins - do not have any strong or innate social proclivity to engage in group and community, their groupishness must be culturally inculcated upon them. Yet, it is astounding to see what has happened in terms of groupishness within less than 10,000 years from the transition from gatherer-hunter forms of living to early agricultural forms of life. We have exponentially enhanced our social living to the extent of modern megalopoleis like Seoul, with 25 million people, or the North-East American coast with almost 65 million people. How could such an increasingly drastic development occur, and what are the implications of this for the understanding of selfhood? An important driver in this evolution has been religion, since evolutionarily it has allowed self-centred despotic apes to become social (Turner et al. 2018). Contrary to bees and ants that are bio-programmed for their sociality and hence eusocial, the hominin lineage is ultrasocial (Turchin 2016, 14f.). It is by means of culture and religion that the ape can be tamed and turned into an ultrasocial being, deliberately willing to give up some of its natural self-insistence.

\section{Hominin vs. other animal forms of selfhood}

The difference between humans and other animals does not lie in humans' possession of culture understood as socially transmitted learning. There is nothing innate about Japanese macaque monkeys washing sand from their potatoes before eating them. It is not something for which they have a special bio-programmer. They do it because they have learned it by imitating others in the group. ${ }^{18} \mathrm{Sim}$ ilarly, when chimpanzees succeed in obtaining food by using different tools for gaining access to termite mounds, they are capable of this by cultural capacity. There is, however, one crucial difference between hominin and hominid culture. The utensils used for getting access to termite mounds remain the same over time. They are never refined. But if one takes a look at the history of, for instance, the fork and knife during the past two centuries, it is obvious how they have

18 Imitation is one of the most important elements in dissemination of social learning, and it cannot be confined to human beings only, but it takes on special forms in the context of hominin evolution, see Laland 2017, 150-74. 
continuously undergone refinement in terms of increasing complexity. This distinction is significant. Many animals possess culture, from corvids to apes, from capuchin monkeys to porpoises; but they do not have cumulative culture which is the hallmark of hominin evolution (Henrich 2016, 56f., 286-95; Laland 2017, 8-11, 183-6). As I have already said there is now abundant evidence that a number of animals, apart from having culture, also have a sense of selfhood - wherefore self-recognition cannot be confined to the hominin lineage only. Goodall argues with respect to chimpanzees that:

They are capable of intellectual performances that we once thought unique to ourselves,
such as recognition of self, abstraction and generalization, cross modal transfer of infor-
mation, and theory of mind. They have a sense of humor [...] Perhaps, after all, it is not
so ridiculous to speculate as to whether chimpanzees might show precursors of religious
behaviors. In fact, it seems quite possible that they do.

Others have argued along the same lines that something similar may be found with elephants, parrots, corvids and whales (de Waal 2016; Lents 2016). The premise for the argument has often been Darwin's famous claim that: 'Nevertheless the difference in mind between man and the higher animals, great as it is, certainly is one of degree and not of kind' (1936, 494). Whatever this amounts to, it makes it even more important to have a clear terminology when we speak about selfhood, self-awareness and individualisation. It is at this point that I embark on my typological considerations.

Unlike Waal, Goodall, Lents and a great many other primatologists and natural scientists, I am sceptical towards thinking about natural selection in terms of a unidirectional movement. I endorse the gene-culture coevolution perspective as the most plausible way for thinking about evolution. Any species needs to be understood on the background of its distinct niche. ${ }^{20}$ The hominin lineage is special by virtue of the role that culture has come to play in the geneculture evolution relationship. Laland and Henrich among others in different ways argue that hominin evolution is characterised by cultural evolution gaining the upper hand in the gene-culture relationship in such a way that it eventually became the primary driver in the hominin evolution (Henrich 2016, 57; Laland 2017, 234, 318). ${ }^{21}$

19 For strongly ritualised behaviour among chimpanzees, see Kühl et al. 2016.

20 For niche construction theory and its impact for how we should understand evolution, see in particular Odling-Smee, Laland and Feldman 2003, Bickerton 2009 and Laland 2017.

21 Whereas Henrich dates this constellation to around two million years ago, Laland asserts that it is a relatively new situation occurring at the transition from the gatherer-hunters' form 
An important part of Laland's argument is the appearance of protolanguage and thus a provisional form of symbolic thinking already 1.7 million years ago (2017, 175-207, and in particular 205; cf. Bickerton 2003, 213-21). Most scholars date the emergence of symbolic competence to around 450,000 years ago, so it makes a huge difference that Laland and Bickerton locate it another 1.2 million years back in time at the transitional stage from Oldowan culture, which remained the same over almost a million years, to the emergence of Acheulian hand axes signifying an important refinement in tool making. Whether Bickerton is right that it was the need for power scavenging that triggered the emergence of protolanguage or, as in Laland's argument, it was the need for high fidelity teaching that prompted it needs not concern us here. The crucial point is the appearance of symbolic communication. This evolutionary leap had decisive influence on the level of self-awareness that we can plausibly impute to our distant predecessors (cf. Peirce 1932, 186).

There is a great variety of different forms of self-recognition among animals other than humans, ${ }^{22}$ but the hominin capacity for symbolic language and, thus, capacity for self-awareness cannot be underestimated in terms of making a decisive evolutionary difference. Apes that have self-recognition are by means of indexical communication confined to the here and now of sign transmission. Only species that have symbolic competence can transcend the hic et nunc of present communication, wherefore we also attribute to them alone the ability of conceptual thinking. The possession of concepts allows the hominin species to communicate about things that are not immediately present in their environment, whether spatial or temporal. As demonstrated by Rappaport, symbolic competence also involves a number of problems such as the risk of being exposed to lying - other animals can be very sly in deception, but they cannot lie since it presupposes symbolic communication (Rappaport 1999, 11-7, 415f.). My basic argument is that we may well attribute to a number of animals the ability to recognise themselves as different from other animals, kin and the remaining group, but it does not make sense to accord self-awareness to any other animal but the hominin lineage of the last 1.7 million years. It takes a concept of the self in distinction from not only other selves, but also the group, before we can speak about a genuine form of selfhood.

\footnotetext{
of culture to early agriculture around 10.000 BCE. Laland argues that the situation from around four to two million years ago to the appearance of early agriculture was characterised by equal determinacy in the gene-culture relationship.

22 If, for instance, one amputates an arm from an octopus the octopus will not eat the arm. Had the arm been one from another octopus it would have eaten it. The example may appear excessive, but it presupposes that a sense of self-recognition needs to be attributed to the octopus.
} 


\section{Typological reflections on the evolution of the self: from self-mirroring to individualism}

Having argued for a first crucial distinction between self-recognition, found in a variety of animals, and self-awareness as distinct to the hominin lineage from around 1.7 million years ago, it makes sense to search for further leaps. We know that some animals are capable of recognising themselves in a mirror, hence self-mirroring, but that involves neither self-awareness nor suifaction. It takes a mindful species, self-conscious of its choices, to engage in stronger forms of self-recognition. Obviously this change did not happen all at once. On the contrary, it was a long evolutionary transition from protolanguage to a more developed form of language that occurred sometime during 200,000 to 100,000 BCE. The existence of cave paintings from the latter part of 100,000 BCE and the use of ochre and pearls already around 100,000 BCE demonstrates the spread of conceptual thinking with ramifications of suifaction and, thus, a stronger sense of self-awareness. When humans can be portrayed in hunting scenes and human ornamentation can be documented, this surely testifies to incipient processes of selfhood.

Similarly important changes in self-understanding occurred at the transition from gatherer-hunters' forms of culture to early forms of agriculture with the earliest types of semi/-permanent habitations. The sharing of land and a sense of belonging to one particular place will inevitably have had consequences for one's notion of selfhood in relation to other members of the group, just as inheritance of land through kinship strengthened one's sense of belonging to a smaller group within the community. Unfortunately we do not know much about this transition given the lack of written sources.

The next important change took place around 6000 years ago with the earliest forms of urban culture emerging in the Near Orient. The figure of the divine king and, from the invention of writing, textual instantiations of him points to a shift in understanding with respect to at least one prominent self. Although this figure was seen as different from the remaining group by his distinct relation to the divine, he was not understood as constituting an independent self. On the contrary, it was his double nature as divine and human that gave him a specific role or function. The urban forms of religion gave rise to new forms of individuation that called for an enhanced awareness of differences between society at large, one's local community, kin-group and self. The basic premise, however, of such religions is the maintenance of a proper balance between the divine and the human, a culturally imposed fundamental ontological differentiation that serves to keep the two spheres at a proper distance from each other. Crises occur in the 
form of blessings withheld from humans (e.g. wine, fat oil, abundant harvest, numerous descendants), when the proper distance is not observed and the two realms approach each other too closely. At the vertical axis heaven and earth should be kept apart, just as the temple institution at the horizontal spatial axis functioned to retain proper distance between the realms.

In Israelite religion, for instance, the high priest once a year would enter the holy of holies to cleanse it from all the ontological impurity brought upon it by humans during the previous year with the aim in mind to have the deity return to his sacred abode.

I shall not dwell on this transition to complex urban culture, since in my view it did not lead to any major change in the understanding of selfhood: a fact that may be inferred from the ideology at stake. What Smith aptly dubbed as the locative type of religion characteristic of one particularly prominent strand of religion in the ancient Mediterranean religions is exactly this complex urban form of religion (cf. Smith 1990, 121f.). Smith failed, though, to see how it was the divine king only who was assigned a distinct role, in some of these forms of religion, to be incorporated into and, eventually, translocated to the divine world, and how all other humans were enjoined to remain at their proper place within the cosmic order. These religions were all concerned with putting man, and only secondarily woman, in their proper place and even more importantly safeguarding that they remained there. Such an ideology is not likely to have promoted a strengthening in suifaction. Therefore, I shall proceed to the grand changes that took place in elite segments in some Eurasian societies during the period from the sixth to the third century BCE. These transitions were contemporaneous with the complex urban type of religion, but they also pointed forward to a new form of religion that would increasingly become disseminated to wider segments of populations and show itself more adaptive to far larger communities, hence my term early kosmos forms of religion. ${ }^{23}$ It is the emergence of this form of religion that has often been dubbed the Axial age transformation of religion (Bellah 2011a). I consider this transition - comparable to Smith's category of utopian forms of religion - crucial also in terms of paving the way for an intensified understanding of the self and a concomitant ideology of selfhood. I have previously characterised this transition by 12 points that, to a greater or lesser extent dependent upon the particular culture in question, highlight some of the main changes with respect to the contemporaneous urban religion (Petersen 2017a; 2017b; Turner et al. 2018). Here I

23 Norenzayan (2015) is also concerned with this change, but contrary to my argument he reverses the order of events. He asserts that 'big gods' were conducive to larger societies, whereas I argue that 'big gods' were a result of changed infrastructure, enhanced density in population, and a growth in urbanisation with concomitant increased labour division. 
shall only highlight five points of special importance for a different concept of the self:

(1) An increased form of self-reflexivity as a 'thinking about thinking' in these forms of religion is closely related to a foundational epistemology expressed in spatial categories, whereby differences between opposing views are projected onto a vertical axis and expressed as a contrast between the heavenly over and against the mundane perspective. This dualistic staging is similarly projected onto an axis of depth that implies a disparity between interiority and exteriority, soul and body (cf. Petersen 2015, 71-6, 89);

(2) These forms of religion are distinguished from comprehensive urban religions by loosening the ontological differences between gods and humans. Therefore, they encourage adherents to imitate the godhead to such an extent that eventually the followers are thought to transcend the ontological difference between divine and human (cf. Petersen 2013b);

(3) They place emphasis on the element of askēsis, understood in the basic Greek sense of training. By engaging in forms of self-exercises, the practitioners undergo different forms of privations relating to what they consider false values while striving to inculcate the principles of their new worldview by embodying them in a continuous form of self-cultivation (cf. Hadot 1995; 2001; Sloterdijk 2009; Petersen 2013b);

(4) Early kosmos types of religion exemplify a shift in emphasis from the ritual observances of traditional religious sacrifices to various forms of inner attitudes as a prerequisite for proper cultic observance. This is sometimes called the displacement of ritual by moral stance. It is not traditional cult per se that is criticised. What is called for is a moral attitude reflecting the new worldview as a presupposition for observing rituals in the proper manner (cf. Petersen 2017a);

(5) The emergence of this form of religion characteristically occurs in a situation of considerable social competition involving religious entrepreneurs' dissociation from the ruling elite - whether political or religious or both - and defiance against traditional kinship structures and political power as well as a plea for greater equality and social justice (cf. Abrutyn 2014; 2015);

I do not argue that these five characteristics were all present in the same way in, for example, the Upanishad literature, early Buddhism, Daoism, Confucianism, Platonic philosophy, and Deuteronomian theology; but they were permeating all these different kosmos forms of religion to greater or lesser extents. In pointing to the early kosmos religions as a crucial stepping stone for the later developments I do not argue for a unidirectional, irreversible progressive movement. Subsequent processes within the individual religions and cultures were characterised by both 
greater embracement of urban types of religion and correspondingly in other strands detachment from them by enhanced emphasis on selfhood, but I assert that they could not avoid relating to what had preceded them in a determinative ideological way (Petersen 2018). We see this in a variety of religions in which there were periods with increased individualisation and de-individualisation, just as the two processes often went hand in hand in rivalries and contestations between different groups that within the individual cultures accentuated individualisation at the cost of de-individualisation or vice-versa. Such processes eventually gave rise to the modern Western individual (as well as all other cultures influenced by this tradition) and an undergirding ideology of individualism subsequent to Enlightenment and Romanticism.

\section{Two examples of suifaction illustrating the shift from urban to kosmos forms of religion}

To avoid being accused of mere theoretical speculation, I now turn to two historical cases to illuminate my point of the kosmos forms of religion as particularly relevant for the discussion of selfhood and processes of individualisation in cultural history. The first example comes from Deuteronomy and is representative of Deuteronomian theology. ${ }^{24}$ It is particularly interesting because it represents an intermediary stage between an urban and a kosmos type of religion. We do not know its precise date of origin, but a presumable date sometime around the middle of the first millennium BCE is likely. The second example comes from a late stage in Stoicism, from Epictetus and Seneca, and serves to illustrate a more complex form of kosmos religion, but certainly one the contours of which may be seen in Deuteronomy, hence my choice of empirical material comes from two different religio-cultural contexts in terms of time and space.

Deuteronomian theology is not confined to the Book of Deuteronomy, and was determinative for the shaping of the mythic narrative depicting Israel's history until the Babylonian exile as found in Joshua, Judges, 1 and 2 Samuel and 1 and 2 Kings. Similarly, it has exerted important influence on the shaping of what eventually became the Pentateuch, just as it had impact on other writings such as parts of the prophetic literature. I shall not delve into these issues, but will

24 For the general historical discussion of Deuteronomy and Deuteronomian theology, see Otto 2007, 137-46, and Kratz 2013 and 2015, 53f., 115-20. I am indebted to Prof. Jensen for conversations on the Axial nature of Deuteronomy and deuteronomian religion as well as Jensen 2017. 
focus on suifaction as it appears in the Book of Deuteronomy- regardless of its close connection to the Book of Joshua - and concentrate on the Book in its final redactional form dating sometime during the fourth to the early third century BCE (cf. Otto 2013, 211; Collins 2017, 39-41).

At the same time as Deuteronomy exemplifies the kosmos type of religion, it also testifies to a great many features characteristic of the urban form of religion. A good life consists in the blessings sent by YHWH to his people in the form of fat oil, good wine, crops, abundant offspring etc. Israel will continue to receive YHWH's blessings as long as it remembers its contractual lord and does not replace him with other gods/idols. Contrary to the priestly theology of notably Leviticus, the cult with the temple and the different regulations relating to it are not the prime focus of Deuteronomy. YHWH's name is present in the temple (14:23), but, contrary to the core idea of the priestly theology, YHWH is not understood himself to inhabit the temple. YHWH is in heaven (26:15). In fact, Otto has argued that the priestly theology may be seen as a counter-programme to the Deuteronomian religion (234). Israelites should visit the temple and partake in the cult by bringing sacrifices at the yearly pilgrim feasts; ${ }^{25}$ but Deuteronomy is not particularly concerned with the temple and its cult. The focus lies on the land that Israel inherited from YHWH as its special property. In this way, Deuteronomy together with Deuteronomian theology bears witness to a classic urban form of religion founded on the principle of ethnicity. Israel constitutes an ethnic enclave in a world surrounded by foreign people and other gods - whether they be extraor simply disloyal intra-kin people (cf. Collins 2017, 42) - and Israel will remain a divine reserve only by worshipping YHWH who has granted Israel its distinct piece of land.

Contrary to all these elements that inevitably connect Deuteronomian theology with an urban form of religion, there are features in Deuteronomy that point in another direction. Moses enjoins Israel to follow the statutes ('l-hhqym) and judgements (w'l-hmšptym) which he teaches them (4:1a). They shall observe them that they may live, enter and possess the land which YHWH has given them (4:1b). Therefore, they are also inculcated not to add to or take away from the commands (mșût) given by YHWH (4:2). The statutes and judgements imposed on Israel by YHWH and Moses constitute their wisdom (hkmtcm) and understanding (byntcm) before all other people who will thereby come to acknowledge Israel as being in possession of these qualities (4:6). In fact, Israel is distinct and

25 Presumably the cult of worship is located at Sichem and not Jerusalem, which is not even mentioned in the book. It is only due to the larger and later framework of Pentateuchal theology that Jerusalem comes to be identified with the place of cultic worship in Deut. 
privileged when compared with all other nations by virtue of the fact that it has YHWH so near to it (4:7), and that it has been granted 'such statutes (hkm) and righteous ordinances (wmšptym șdyqm) as all this law (htôrh hz't) which I set before you this day' (4:8).

Demonstrably Torah is a polyvalent term, since by tradition it refers to the Pentateuch, sometimes the entire Tanak, as well as the full complex of rules and ordinances which YHWH according to the Pentateuch gave the Israelites at Mount Sinai/Horeb (cf. Cohen 1987, 182-5, and more generally Hayes 2015). Here, however, Torah is a common denotation for the authority attributed to various norms, regulations, ordinances, injunctions and prohibitions understood to originate in YHWH's bestowal of the Law on Israel.

The text, however, does not only speak in the second person plural but occasionally makes leaps in its discourse to second person singular as, for example, in 4:9: 'Only take heed to yourself ( $h \check{m} m r$ ), and diligently keep yourself (wšmr), lest you forget ( $t$ škh $)$ the things your eyes have seen, and lest they depart from your heart all the days of your life. And teach (whôd'tm) them to your children and your grandchildren.' Here Israel is not only addressed as a collective entity but every Israelite man is personally obliged to preserve the continuous remembrance of YHWH's deeds in order to prevent them from falling into oblivion. We find the same transition in discourse in the important chapter 6, containing the Shema, in which every Israelite man is enjoined to have the words of YHWH in his heart (6:6). He shall teach them diligently to his children, and shall talk of them, when he sits in his house, when he walks on his way, when he lies down and when he rises up (6:7). He shall bind them as a sign (l'ôt) on his hand and they shall be as frontlets between his eyes (6:8), just as he shall write them upon his door-posts of his house and his gates (6:9). This unremitting emphasis placed on the Torah as a set of regulations to be continuously remembered involves an incessant training program for every Israelite man who is called to unceasingly think of YHWH and his deeds and to inculcate this remembrance in his household. Deuteronomy presents itself in this way as 'the Book of the Law' (bsphr htôrh hzh) containing YHWH's commandments and statutes (mṣôtyw whqtyw) (30:10a). Every Israelite man should turn to YHWH as his god with all his heart and soul (30:10b), and make sure that the word of God is in his mouth and in his heart so that he may perform it (30:14).

I do not argue that Deuteronomy and Deuteronomian theology represent a full-blown kosmos form of religion. It remains deeply enmeshed in the urban type of religion. What I do claim, though, is that this theology testifies to a process of increasing suifaction that would eventually let go of its dependence upon those features of religion belonging to the urban type. The more the emphasis is placed on the self and its need for self-cultivation in order to pay heed to the Torah of 
YHWH, the less one needs the ethnic group (Israel) and the land (the territory) for the overall worldview. By Deuteronomy's strong emphasis on Israel's exclusive allegiance to YHWH and the role of the self unremittingly to instill within itself its specific obligation and faithfulness to YHWH, the self comes to the fore of religious attention. By virtue of such an understanding the religious community is increasingly transformed from an ethnic entity into a community of shared commitment to YHWH (cf. Gerstenberger 2002, 207-72; Crouch 2014, 109). Deuteronomy reflects a high degree of equality among YHWH-abiding Israelite males who form a 'theocratic' community on the basis of their commitment to YHWH. They are accountable to YHWH only and do not have any Davidic king interfering between them and YHWH (cf. Markl 2012, 301; Otto 2013, 226). In this way, the book represents a form of thinking that vacillates between processes of indvidualisation and de-indivdualisation. The former points forward towards more complex forms of kosmos religion which by exclusive focus on self-cultivation may eventually abandon its determinative dependence upon principles of ethnicity, the ontological difference between deity and man, and concomitant 'mundane' blessings sent by YHWH to Israel. The latter points backwards in time to the urban type of religion in contrast to the cosmos form. It accentuates those features which religions focused on self-cultivation, self-mastery and continuous self-training in the end cast off.

All differences aside, I think we may see Stoicism as one distinct manifestation of kosmos religion which - with all the necessary reservations in terms of dissimilarities between archaic Greek and Israelite religion - had abandoned such elements that gave Deuteronomian theology an ambivalent character, ultimately leaving the latter to oscillate between the urban and the kosmos types of religion. ${ }^{26}$ In Stoicism the kosmos form of religion appears at full throttle, but here I confine myself to the element of suifaction and look upon it in terms of self-cultivation specifically as it appears in Epictetus and in Seneca's Letters. There are obvious differences between these two corpora of texts which I shall not dwell upon. It suffices to say that they are, ceteris paribus, training programs urged upon their respective intended addressees with the aim in mind to have them inculcate and follow a Stoic way of life.

Contrary to the urban type of religion, these texts have abandoned the idea of ethnicity as foundational for religious belonging, the notion of an ontological difference as fundamental for upholding the proper balance between the divine and the human world, and the understanding of 'worldly' blessings as the divine

26 For ancient philosophy as representative of religion, from the third order perspective, see Petersen 2017a; 2017b. 
boons par excellence. The philosopher does not belong to any particular ethnicity in this world, but is a kosmopolitēs, a man belonging to the entire universe (cf. Epictetus 1.9.2, 1.9.5, 2.10.3). As both Epictetus and Seneca make copiously clear, the philosopher in particular has kinship with God (cf. Seneca 18.12f., 91, 123.16; Epictetus 1.9.4-6, 1.9.25, 1.14), just as by his training he has learned to be unconcerned about worldly blessings such as, for instance, wealth and well-being. In fact, he should set himself free from all worries and unnecessary concerns by devoting himself to philosophy as constituting, in the words of Hadot, a way of life.

From their beginning, Seneca's Letters to Lucilius and Arrian's Discourses of Epictetus are meant to mould the intended addressees in such a way that they concern themselves with what lies within their abilities to do something about and leave all other things behind for the sake of this. By the use of reason they have been granted a faculty that if properly trained will allow them to exert mastery over their lives. The self-mastery brought about by continuous selfcultivation is the ultimate aim of these texts through which Arrian (rendering the speeches of Epictetus) and Seneca goad their addressees into pursuing a good mind (cf. Seneca 23.1, 37.1 ad bonam mentem). Surely one cannot avoid the contingencies and necessities of life, but through the philosophical way of life one can learn to conquer them (cf. Seneca 37.3). In an epistle concerned with Lucilius' promise and oath to become a good man (vir bonus, 37.1), Seneca spells out how philosophy provides him with a way (et hanc tibi viam dabit philosophia) that will make him sound (salvus), unconcerned (securus), happy (beatus), and, most importantly, free (liber) (37.3). Only by way of philosophy can this goal be reached, since it enables one to put all things under the control of reason (ratio) and, thereby, have folly (stultitia) and the most cruel passions (affectus multi savissimi) subdued (37.4).

The endurance and dispassionate mind that can be obtained through philosophy is also a major concern of Epictetus. To avoid falling victim to external impressions (phantasiai) the philosopher has, through the faculty of reason, been enabled to handle them in the right way (chrēsis orthē, 1.1.7, cf. 1.1.12). By the proper use of judgement on these external impressions such as, for instance, death, the philosopher through reason is capable of applying the powers of choice and refusal, desire and aversion, whereby he can come to master them (cf. 2.18.24f., 3.8.1-5).

The idea of training or askēsis permeates all of Seneca's and Epictetus' texts. The philosopher needs to engage in continuous training which will enable him to remain within the philosophical world as a way of life. In chapter 12 of the third book of Arrian's Discourses of Epictetus, he takes up the issue of training specifically. Philosophers should not engage in training in things that are against nature 
(dia tōn para phusin) or paradoxical (paradoxōn), since they cannot do anything about this. Rather they should train in order to obtain the faculty of acting unhindered with respect to choice and aversion (orexei kai ekklisei akōlutōs anastrephesthai, 3.12.4). Thereby they will neither fail to get what they desire (mète oregomenon apotungkhanein), nor fall into what they would avoid (mèt ekklinonta peripiptein):

For since it is impossible without great and constant training (aneu megalēs kai sunechous askēseōs) to secure that our desire fail not to attain, and our aversion fall not into what it would avoid, be assured that, if you allow training to turn outwards, towards the things that are not in the realm of the moral purpose, you will have neither your desire successful in attaining what it would, nor your aversion successful in avoiding what it would.

(3.12.5 - LCL translation by Oldfather)

Similar to other representatives of kosmos forms of religion like Siddhartha Gautama, Confucius and Socrates, the Stoic philosopher in Epictetus' understanding should make his self entirely independent of culture by spending his time on self-cultivation. This will enable him to make progress in desire and aversion and thereby obtain autonomy of mind.

In several studies, Gill has made the point that the Stoic tranquility and autonomy of mind is conspicuously different from the modern post-Cartesian and Kantian one. I agree. Gill insists on the difference between what he terms subjective(-individualist) and objective(-participant) selves, where the latter designates the ancient view and the former the modern Western one (2006, 328-44; 2008, 359-61). There is nothing in the Stoic view, or any other ancient perspective on selfhood for that matter, that suggests anything close to the modern detached autonomous subject. The Stoic philosopher and other ancient person can only obtain what he aspires to by having been granted that faculty by the gods or God. The self is always involved in a relationship to superhuman powers. That said, however, we see in the examples provided a transition towards a far greater emphasis placed on the self and the need for this self to engage in a deliberate process of training self-cultivation. Once again, however, I stress that this did not imply the emergence of the individual, but it constituted the beginning of a long journey lasting at least 1700 years by which suifaction increasingly came to be understood in terms of self-cultivation, and by which these processes of self-cultivating individualisation became increasingly prolific in emphasis on the self at stake (cf. Sloterdijk 2009).

\section{Conclusion}

Admittedly, the argument put forward is convoluted, so I allow myself to summarise the main points of the typology developed. I assert that: 1) a sense of 
selfhood, that is self-recognition, is found in several animals in addition to the hominin species, but this sense, ceteris paribus, is confined to the hic et nunc of animal communication; 2) genuine self-awareness, therefore, is neither found among other animals nor in the hominin lineage prior to the emergence of protolanguage, at the earliest around 1.7 million years ago with the appearance of Acheulian culture, and this change constituted a precondition for engaging in conceptual thinking about being a 'self' that was not confined to the here and now of discourse; 3) a stronger form of suifaction emerged with Homo sapiens with a fully developed language and capacity for ornamentation, painting and, thereby, external memory storage around 100,000 BCE; 4) there were leaps towards stronger self-understanding and, thereby, processes of individualisation at the transitions from hunter-gatherer culture to early agriculture and, similarly, from complex agricultural culture to early urban culture; 5) the emergence of early forms of kosmos religion and the transition from complex urban religion to this type of culture was decisive for the subsequent development in terms of intellectual history; 6) the further intensification in dominant forms of thinking about suifaction all had the change from urban to kosmos or the transition from archaic to Axial age religion as an ideological presupposition; 7) and, finally, that the very strong forms of individualisation and individualism that we see in connection with Enlightenment and Romanticism be thought of as a further escalation in suifaction rather than something categorically novel.

An important point of these typological ruminations has been to argue how historical changes in selfhood, self-awareness, and suifaction are best understood as degrees of intensification resulting from transitions in the distinct niche of the species in focus. Chimpanzees, for example, are not in need of any extensive self-recognition or any self-awareness for that matter, since they inhabit an environment in which there are no evolutionary gains related to complex language and, thus, suifaction. This is different from the hominin lineage that ever since its appearance in the open grasslands has been in decisive need of engaging in alliances and co-operations in order to survive. To succeed with that, language, self-awareness, suifaction and individualisation became incrementally crucial. What was once needed in Uruk in terms of suifaction in the third millennium BCE, did not suffice in fifth century Athens. But the degree of suifaction needed for coping with living in fifth century Athens would not help much in present day New York. These are the differences in terms of gradations of selfhood between different socio-cultural environments that the typology suggested is meant to highlight.

Finally, two historical examples illustrate my point that something decisive took place in terms of suifaction at the shift from urban forms to kosmos types of religion. At first, it was a transition found in some elite Eurasian cultures only, 
but eventually the idea of self-cultivation became disseminated to greater segments of populations. The example from Deuteronomy testifies to a form of thinking that oscillates between an urban form of religion and a kosmos one. There are features that strongly unite it with the former, whereas there are others that point forward in what was to evolve at a more full scale in the history of religions. My final example from Stoicism represents self-cultivation at full measure. Life is understood as a continuous ideological training-program for the sage, which enables him to detach himself from the influence of harmful external impressions and, thereby, cures him from the malaise pertaining to this world. The stoic sage, though, was no individual in the modern sense. His whole world is directed towards God as his helmsman. Nevertheless, the emphasis placed on selfcultivation marks a transition as regards the extent to which humans are called to engage in processes of suifaction. The understanding of suifaction in subsequent forms of religion all had to respond to this very prominent change in thinking, whether negatively or positively. The modern individual and the concomitant ideology of individualism may be understood as a particularly strong version of suifaction, by which the self is now all on its own - or as Wilhelm Müller would have it: 'Lustig in die Welt hinein. Gegen Wind und Wetter! Will kein Gott auf Erden sein. Sind wir selber Götter!' ('Happy through the world along. Facing wind and weather! If there's no God upon earth, then we ourselves must be gods!’ translation Celia Sgroi) (Schubert Winterreise).

\section{References}

Abrutyn, Seth. 2014. 'Religious Autonomy and Religious Entrepreneurship: An EvolutionaryInstitutionalist's Take on the Axial Age', Comparative Sociology 13, 105-34.

Abrutyn, Seth. 2015. 'The institutional evolution of religion: innovation and entrepeneurship in ancient Israel', Religion 45 4, 505-31.

Arweiler, Alexander; Möller, Melanie (eds.). 2008. Vom Selbst-Verständnis in Antike und Neuzeit: Notions of the Self in Antiquity and Beyond. Transformationen der Antike 8. Berlin/New York: De Gruyter.

Barton, Carlin A.; Boyarin, D. 2016. Imagine No Religion: How Modern Abstractions Hide Ancient Realities. New York, NY: Fordham University Press.

Bellah, Robert N. 2005. 'What Is Axial about the Axial Age', Archives Européenne de Sociologie XLIV 1, 69-89.

Bellah, Robert N. 2011a. Religion in Human Evolution: From the Paleolithic to the Axial Age. Cambridge, MA/London: The Belknap Press.

Bellah, Robert N. 2011b. 'Nothing is ever lost: an interview with Robert Bellah by Nathan Schneider', http://blogs.ssrc.org/tif/2011/09/14/nothing-is-ever-lost. (Last access March 14, 2018).

Bickerton, Derek. 2009. Adam's Tongue: How Humans Made Language, How Language Made Humans. New York, NY: Hill and Wang. 
Bonnet, Corinne. 2013. 'The Religious Life in Hellenistic Phoenicia: “Middle Ground” and New Agencies.' In The Individual in the Religions of the Ancient Mediterranean, ed. J. Rüpke, Oxford: Oxford University Press. 41-57.

Burckhardt, Jacob. 1985. Die Kultur der Renaissance in Italien: Ein Versuch. Neudruck der Urausgabe (ed. K. Hoffmann). Stuttgart: Kröner Verlag.

Burridge, Kenelm. 1979. Someone, No One: An Essay on Individuality. Princeton, NJ: Princeton University Press.

Certeau, Michel de. 1975. L'Écriture et l'Histoire. Bibliotèque des Histoires. Paris: Gallimard.

Cohen, Shaye. 1987. From the Maccabees to the Mishnah. Library of Early Christianity. Louisville, KY: John Knox Press.

Collins, John J. 2017. The Invention of Judaism: Torah and Jewish Identity from Deuteronomy to Paul. The Taubman Lectures in Jewish Studies 7. Oakland, CL: University of California Press.

Crouch, Carly L. 2014. The Making of Israel: Cultural Diversity in the Southern Levant and the Formation of Ethnic Identity in Deuteronomy. VT SS 162. Leiden: Brill.

Darwin, Charles. 1936. The Origin of Species by Means of Natural Selection or the Preservation of Favored Races in the Struggle for Life \& The Descent of Man and Selection in Relation to Sex. New York: The Modern Library.

de Waal, Frans. 2016. Are We Smart Enough to Know how Smart Animals Are? New York, NY: W. W. Norton.

Dumont, Louis. 1983. Essais sur L'individualisme: Une perspective anthropologique sur l'ideologie moderne. Paris: Seuil.

Dumont, Louis. 1986. Essays on Individualism: Modern Ideology in Anthropological Perspective. Chicago/London: Chicago University Press.

Durkheim, Émile. 1898. 'L'individualisme et les intellectuels', Revue bleu 4e série t. X, 7-13. Made accessible by Marcelle Bergeron at l'École Dominique-Racine Chicoutimi, Québec at: http://classiques.uqac.ca/classiques/Durkheim_emile/sc_soc_et_action/texte_3_10/ individualisme.pdf. 3-17.

Durkheim, Émile. 1995. The Elementary Forms of Religious Life. Transl. Karen Fields. New York, NY: The Free Press.

Durkheim, Émile. 2007. Les formes élémentaires de la vie religieuse. CNRS Éditions. Paris: CNRS.

Fuchs, Martin et al. 2016. 'Religious Individualization in Historical Perspective: Research Program 2014-17', In First Results of the Second Funding Period of the Research Group 'Religious Individualisation in Historical Perspective' (2013-2015): A Reader, ed.

R. Suitner, Erfurt: Max Weber Centre, Universität Erfurt. 9-24.

Gerstenberger, Erhard S. 2002. Theologies in the Old Testament. London: Bloomsbury.

Gill, Christoper. 2006. The Structured Self in Hellenistic and Roman Thought. Oxford: Oxford University Press.

Gill, Christoper. 2008. 'The Self and Hellenistic-Roman Philosophy.' In Vom Selbst-Verständnis in Antike und Neuzeit: Notions of the Self in Antiquity and Beyond, eds. A. Arweiler, M. Möller, Transformationen der Antike 8, Berlin/New York: De Gruyter. 359-80.

Goodall, Jane. 2005. 'Do Chimpanzees Have Souls: Possible Precursors of Religious Behavior in Animals.' In Spiritual Information: 100 Perspectives on Science and Religion, ed. C. L. Harper, Philadelphia/London: Templeton Foundation Press. 274-9.

Gordon, Richard L. 2015. 'Religious Competence and Individuality: Three Studies in the Roman Empire', Religion 45/3. 367-85. 
Graf, Fritz. 2013. 'Individual and Common Cult: Epigraphic Reflections.' In The Individual in the Religions of the Ancient Mediterranean, ed. J. Rüpke, Oxford: Oxford University Press. 115-35.

Hadot, Pierre. 1995. Qu'est-ce que la philosophie antique? Paris: Éditions Gallimard.

Hadot, Pierre. 2001. La philosophie comme manière de vivre: Entretiens avec Jeannie Carlier et Arnold I. Davidson. Paris: Albin Michel.

Haidt, Jonathan. 2012. The righteous Mind: Why Good People Are Divided by Politics and Religion. London: Penguin Books.

Hayes, Christine. 2015. What's Divine about Divine Law? Early Perspectives. Princeton, NJ: Princeton University Press.

Henrich, Joseph. 2016. The Secret of Our Success: How Culture Is Driving Human Evolution, Domesticating Our Species, and Making Us Smarter. Princeton, NJ: Princeton University Press.

Jensen, Hans Jørgen Lundager. 2017. 'Fire indgange til gammeltestamentlig teologi. Anmeldelse af Anne Katrine de Hemmer Gudme, Søren Holst, Jesper Høgenhaven og Frederik Poulsen, Fire indgange til gammeltestamentlig teologi, København: Det Teologiske Fakultet 2016', http://bibliana.dk/2017/01/fire-indgange-til-gammeltestamentlig-teologi (last access August 25, 2017).

Jensen, Jeppe Sinding. 2009. 'Conceptual Models in the Study of Religion.' In The Oxford Handbook of the Sociology of Religion, ed. P. B. Clarke, Oxford: Oxford University Press. 245-62.

Jensen, Jeppe Sinding. 2014. What Is Religion? London: Routledge.

Kratz, Reinhard G. 2013. “"The peg in the wall”: Cultic Centralization Revisited.' In Law and Religion in the Eastern Mediterranean: From Antiquity to Early Islam, eds. A. C. Hagedorn, R. G. Kratz, Oxford: Oxford University Press. 251-85.

Kratz, Reinhard G. 2015. Historical and Biblical Israel: The History, Tradition, and Archives of Israel and Judah. Oxford: Oxford University Press.

Kühl, Hjalmar S. et al. 2016. 'Chimpazee accumulative stone throwing', Scientific Reports 29.02.16.1-8.

Laland, Kevin N. 2017. Darwin's Unfinished Symphony: How Culture Made the Human Mind. Princeton, NJ: Princeton University Press.

Lents, Nathan H. 2016. Not so Different from Us: Finding Human Nature in Animals. New York, NY: Columbia UP.

Lukes, Steven. 1969. 'Durkheim's Individualism and the Intellectuals', transl. by Steven Lukes, Political Studies XVII 1. 14-30.

Lukes, Steven. 1972. Émile Durkheim: His Life and Work: A Historical Critical Study. New York, NY: Harper \& Lee.

Makari, George. 2015. Soul Machine: The Invention of the Modern Mind. New York, NY: W. W. Norrton.

Markl, Dominik. 2012. Gottes Volk im Deuteronomium. BZAR 18. Wiesbaden: Otto Harrassowitz.

Martin, Luther. 1994. 'The Anti-Individualistic Ideology of Hellenistic Culture', Numen 41/2. 117-40.

Mauss, Marcel. 1938. 'Une Catégorie de L’Esprit Humain: La Notion de Personne de “Moi”: Un Plan de Travail', The Journal of the Royal Anthropological Institute of Great Britain and Ireland 68 July-December. 263-81.

Nietzsche, Friedrich. 1985. Jenseits von Gut und Böse: Vorspiel einer Philosophie der Zukunft. In idem, Friedrich Nietzsche Werke in vier Bänden, Band IV, Salzburg: Verlag das Bergland-Buch. 
Nongbri, Brent. 2013. Before Religion: A History of a Modern Concept. New Haven, CT: Yale University Press.

Norenzayan, Ara. 2015. Big Gods: How Religion Changed Cooperation and Conflict. Princeton, NJ: Princeton University Press.

Odling-Smee, F. John; Laland, Kevin N.; Feldman, Marcus W. 2003. Niche Construction: The Neglected Process in Evolution. Monographs in Population Biology 37. Princeton, NJ: Princeton University Press.

Otto, Eckhart. 2007. Das Gesetz des Mose. Darmstadt: Wissenschaftliche Buchgesellschaft.

Otto, Eckhart. 2013. 'The History of the Legal-Religious Hermeneutics of the Book of Deuteronomy from the Assyrian to the Hellenistic Period.' In Law and Religion in the Eastern Mediterranean: From Antiquity to Early Islam, eds. A. C. Hagedorn, R. G. Kratz, Oxford: Oxford University Press. 211-50.

Peirce, Charles Sanders. 1932. Collected Papers. Vol. 2, Elements of Logic., eds. C. Hartshorne, P. Weiss. Cambridge, MA: Harvard University Press.

Pelling, Christopher. 1990. Characterization and Individuality in Greek Literature. Oxford: Clarendon Press.

Petersen, Anders Klostergaard. 2004. 'Philosophical Fragments in a New Testament Perspective.' In Kierkegaard Studies: Yearbook 2004, eds. N. J. Cappelørn, et al., Berlin/ New York: De Gruyter, 39-62.

Petersen, Anders Klostergaard. 2013a. 'Justin Martyr in Search of the Self.' In Religious Dimensions of the Self in the Second Century CE, Studien und Texte zu Antike und Christentum 76, eds. J. Rüpke, G. Woolf, Tübingen: Mohr-Sibeck. 104-29.

Petersen, Anders Klostergaard. 2013b. 'Attaining Divine Perfection through Different Forms of Imitation', Numen LX1.7-38.

Petersen, Anders Klostergaard. 2015. 'The use of historiography in Paul: a case-study of the instrumentalisation of the past in the context of Late Second Temple Judaism.' In History and Religion: Narrating a Religious Past, Religionsgeschichtliche Versuche und Vorarbeiten 68, eds. B. C. Otto, S. Rau, J. Rüpke, Berlin/Boston: De Gruyter. 63-92.

Petersen, Anders Klostergaard. 2017a. ‘Plato's Philosophy - Why not just Platonic Religion?' In Religio-Philosophical Discourses in the Mediterranean World: From Plato, through Jesus, to Late Antiquity, Ancient Philosophy \& Religion 1, eds. A. K. Petersen, G. van Kooten, Leiden: Brill. 9-36.

Petersen, Anders Klostergaard. 2017b. 'Philosophy and Religion and Their Interactions in 4 Maccabees.' In Religio-Philosophical Discourses in the Mediterranean World: From Plato, through Jesus, to Late Antiquity, Ancient Philosophy \& Religion 1, eds. A. K. Petersen, G. van Kooten, Leiden: Brill. 126-58.

Petersen, Anders Klostergaard. 2017c. 'Words and Things: One or Two Things that I Know about Religion', https://religion.ua.edu/blog/2017/02/15/words-and-things-one-or-two-thingsthat-i-know-about-religion. (Last access March 14, 2018).

Petersen, Anders Klostergaard. 2017d. 'Review of Carlin A. Barton and Daniel Boyarin, Imagine No Religion: How Modern Abstractions Hide Ancient Realities, New York, NY: Fordham University Press 2016', http://www.bmcreview.org/2017/06/20170614.html. (Last access March 14, 2018).

Petersen, Anders Klostergaard. 2018. 'Unveiling the Obvious: Synagogue and Ecclesia - Sisters or Different Species?' In Wisdom Poured out like Water. Studies on Jewish and Christian Antiquity in Honor of Gabriele Boccaccini. eds. J. H. Ellens et al., Berlin/New York: De Gruyter. 575-92. 
Rappaport, Roy A. 1999. Ritual and Religion in the Making of Humanity. Cambridge Studies in Social and Cultural Anthropology 110. Cambridge: Cambridge University Press.

Searle, John F. 2001. Rationality in Action. Cambridge, MA/London: MIT Press.

Seidentop, Larry. 2014. Inventing the Individual: The Origins of Western Liberalism. London: Penguin Books.

Sloterdijk, Peter. 2009. Du mußt dein Leben ändern: Über Anthropotechnik. Frankfurt a.M.: Suhrkamp.

Smith, Jonathan Z. 1990. Drudgery Divine: On the Comparison of Early Christianities and the Religions of Late Antiquity. Chicago Studies in the History of Religion. Chicago, IL: Chicago University Press.

Tomasello, Michael. 1999. The Cultural Origins of Human Cognition. Cambridge, MA: Harvard University Press.

Tomasello, Michael. 2009. Why We Cooperate. Cambridge, MA: MIT Press.

Tomasello, Michael. 2016. A Natural History of Human Morality. Cambridge, MA: Harvard University Press.

Taylor, Charles. 1989. Sources of the Self: The Making of the Modern Identity. Cambridge, MA: Harvard University Press.

Turchin, Peter. 2016. Ultrasociety: How 10,000 Years of War Made Humans the Greatest Cooperators on Earth. Chaplin, CT: Beresta Books.

Turner, Jonathan; Maryanski, Alexandra. 2008. On the Origin of Societies by Natural Selection. London: Routledge.

Turner, Jonathan et al. 2018. The Emergence and Evolution of Religion: By Means of Natural Selection. London: Routledge.

Veyne, Paul. 1983. Les Grecs ont-ils cru à leur mythes? Essais sur l'imagination constituante. Paris: Seuil.

Weber, Max. 1963. 'Zwischenbetrachtung.' In idem, Gesammelte Aufsätze zur Religionssoziologie I (fünfte photomechanisch gedruckte Auflage), Tübingen: Mohr-Siebeck. 536-73.

Woolf, Gregory D. 2013. 'Ritual and the Individual in Roman Religion.' In The Individual in the Religions of the Ancient Mediterranean, ed. J. Rüpke, Oxford: Oxford University Press, 136-60. 
